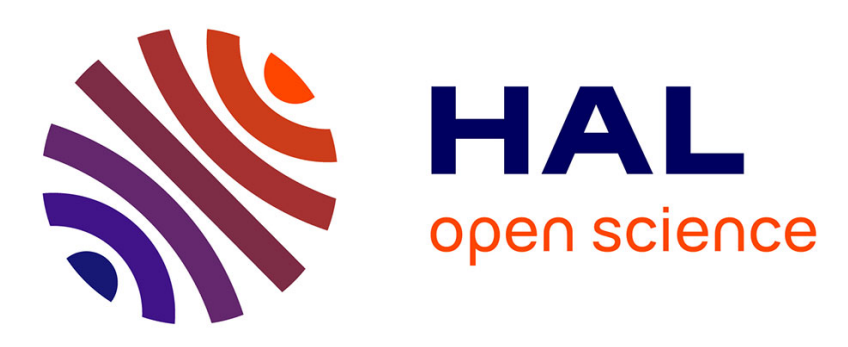

\title{
Modification of cement hydration at early ages by natural and heated wood
}

Alexandre Govin, Arnaud Peschard, René Guyonnet

\section{To cite this version:}

Alexandre Govin, Arnaud Peschard, René Guyonnet. Modification of cement hydration at early ages by natural and heated wood. Cement and Concrete Composites, 2006, 28 (1), pp.12-20. 10.1016/j.cemconcomp.2005.09.002 . emse-00449702

\section{HAL Id: emse-00449702 \\ https://hal-emse.ccsd.cnrs.fr/emse-00449702}

Submitted on 13 Oct 2010

HAL is a multi-disciplinary open access archive for the deposit and dissemination of scientific research documents, whether they are published or not. The documents may come from teaching and research institutions in France or abroad, or from public or private research centers.
L'archive ouverte pluridisciplinaire HAL, est destinée au dépôt et à la diffusion de documents scientifiques de niveau recherche, publiés ou non, émanant des établissements d'enseignement et de recherche français ou étrangers, des laboratoires publics ou privés. 


\title{
Modification of cement hydration at early ages by natural and heated wood
}

\section{Govin AleXANDrE(1)*, Peschard ARnAUd(1), GuYONNET RENÉ(1)}

(1) Ecole Nationale Supérieure des Mines de Saint Etienne, Centre SPIN ; Département PMMC ; LPMG, UMR CNRS 5148, 158 Cours Fauriel ; 42023 Saint-Étienne Cedex 2, France

\begin{abstract}
Heat treatments of wood are widely used for the reduction of wood swelling and dimensional instability of wood-cement composites. The effect of natural and heated wood on the hydration of cement at early ages was investigated by isothermal calorimetry, thermogravimetry (TGA) and Fourier transform infrared (FTIR) spectroscopy. The addition of wood strongly delays and inhibits the hydration of the silicate phases. Consequently, the amount of portlandite is lower in composites than in neat cement. Approximately $30 \%$ of the inhibition of portlandite precipitation is due to an increase of calcium carbonate content in cement paste. The absorption of a part of water by wood produces a decrease in gypsum consumption. Nevertheless, the ettringite formation is not significantly affected since a diffusion of sulfate ions from wood occurs.
\end{abstract}

Keywords:

Hydration; Cement; Wood; Heated wood; Retardation

\section{Introduction}

Thanks to the low thermal conductivity and the good acoustic absorption capacity of woodcement panels, these composites have been developed for thermal insulating and noiseproof walls. These materials present better nailing, durability and fire resistance properties than wood-based particleboards. Moreover, the wood-cement composites are an alternative way to promote the wood industry by-products. However, several difficulties such as dimensional instability due to moisture variations, efflorescence emergence and set retardation, hinder the development of these composites. The set retardation stems from chemical incompatibility between wood, organic material, and the inorganic binder. According to many authors, the effects of wood on cement setting may depend on various factors i.e. the geographical location of the tree, its felling season, its species and its various chemical constituents [1], [2], [3], [4], [5] and [6]. Biblis and Lo reported that the setting time could be related to the amount of soluble reducing sugars [2]. Simatupang, Miller and Moslemi attributed the inhibitory effect of wood on cement setting to the water-soluble hemicelluloses [3] and [4]. Some condensed tannins and gallotannins have also a significant inhibitory effect on cement setting [5] and [6]. Ficher et al. proposed that the detrimental molecule to cement hardening was saccharinic acid resulting from alkaline degradation of soluble sugars [7]. Whistler et al. suggested that wood polysaccharides could be hydrolyzed by alkali media in a large amount of hydroxy-acids and organic acids [8], which are known to be set-retarding agents [9], [10] and [11].

Previous investigations on physico-chemical aspects were restricted to the effect of monosaccharides or sugar acids on cement or single phase hydration [12], [13] and [14].

\footnotetext{
*Corresponding author : govin@emse.fr
} 
Influence of such admixtures on aluminate phase $\left(\mathrm{C}_{3} \mathrm{~A}\right)$ was studied by Young [12] who showed that interaction of sugars with $\mathrm{C}_{3} \mathrm{~A}$ prevented rapid formation of the cubic phase $\mathrm{C}_{3} \mathrm{AH}_{6}$ and promoted the formation of the hexagonal phase $\mathrm{C}_{4} \mathrm{AH}_{13}$. Collepardi et al. [13] found that the addition of glucose, gluconate or lignosulfonate stabilized ettringite in the $\mathrm{C}_{3} \mathrm{~A}$-gypsum system. It was also reported that glucose retarded the gypsum consumption and the ettringite formation. Milestone [14] classified the retarding ability of various admixtures on the hydration of the silicate phase $\left(\mathrm{C}_{3} \mathrm{~S}\right)$. He determined the calcium hydroxide content and a set retarder efficiency which is as follows: sugar acids > sugars > lignosulfonates.

Most of the studies involving modification of cement setting by wood focused on the global behavior of the hydration and the resulting strength of the composite. The objectives of this study were to improve the knowledge of the influence of natural and heated wood particles on the hydration of cement at early ages and to propose a mechanism of interaction between cement and wood materials.

\section{Experimental details}

\section{II.1. Raw materials}

A gray Portland cement (C), CPA CEM I 52.5, was used in this study. The designation follows the French standard NF P 15-301. The chemical composition and mineralogical phases of the cement were calculated by the Bogue approximation [15] and are listed in Table 1.

The wood species used for this study was Poplar sapwood (Populus hybrid I214). Three kinds of fibers were tested: natural Poplar (P), Poplar heated at $240^{\circ} \mathrm{C}(240)$ and Poplar heated at $260{ }^{\circ} \mathrm{C}(260)$. Thermal treatment was carried out according to the retification ${ }^{\circledR}$ [16]process. This treatment consisted of a mild pyrolysis of wood under a nitrogen atmosphere. The swelling of wood is strongly decreased whereas the fungal resistance is enhanced. Treatments were carried out on wood shavings of approximately 2-mm length, stored in a climatic chamber at $20{ }^{\circ} \mathrm{C}$ and $60 \%$ relative humidity.

\section{II.2. Methods of investigation}

Isothermal microcalorimetry, thermogravimetry and FTIR spectrometry were used to monitor kinetics and to determine the mechanism of cement hydration. In each case, cement and wood were mixed for two periods of 2 min using a shaker-mixer (Wab, Turbula, Germany) and the experiments were carried out in triplicate.

Isothermal microcalorimetry carried out on a C80 calorimeter (Setaram, France), enabled the hydration process to be monitored continuously and the admixtures to be classified as retarders or accelerators [10]. The experiments were conducted on a 1-g sample at a deionized water-to-cement weight ratio $(\mathrm{W} / \mathrm{C})$ of $40 \%$ and a wood-to-cement weight ratio $(\mathrm{wd} / \mathrm{C})$ between $2.5 \%$ and $7.5 \%$. Wood powder $(150-200 \mu \mathrm{m})$ was preferred to shavings because of the small size of the cell and the higher specific surface area. Cement and water were mixed outside the calorimeter according to the Sauvat et al. [17] and Ramachandran and Lowery [11] procedures. Consequently, only the exothermic hydration peak was encountered. The temperature of the calorimetric block was maintained at $25{ }^{\circ} \mathrm{C}$.

The natural and the heated wood were sieved between 2-mm and 1.4-mm screens. The fraction of shavings between the two sieves was used in the cement pastes. For samples prepared with natural Poplar, two wd/C ratio: $7.5 \%$ and $20 \%$ were employed. A single ratio fixed at 20\% was used for the heat treated Poplar samples. Cement and water were mixed (mixer Technotest, France) with a W/C ratio equal to 0.4 (w/w), for $1 \mathrm{~min}$ at low speed $(60 \mathrm{rpm})$ and $4 \mathrm{~min}$ at high speed $(120 \mathrm{rpm})$. During hydration, samples were stored in a water-vapor-saturated desiccator and under a nitrogen atmosphere. The hydration of cement was stopped by breaking and grinding hydrated samples and washing them with anhydrous ethanol. In order to avoid modification of the thermogravimetric signal by wood thermal decomposition, the wood was fully removed from the cement pastes by successive screenings. The cement samples were then ground in an agate mortar until each particle size became lower than $100 \mu \mathrm{m}$. This step was repeated at different lengths of hydration time ranging from 1 to $48 \mathrm{~h}$. 
Thermal analysis was performed on a TG-DSC 111 thermogravimetric apparatus (Setaram, France). All experiments were carried out from $20^{\circ} \mathrm{C}$ up to $800{ }^{\circ} \mathrm{C}$ (heating rate of $10^{\circ} \mathrm{C} / \mathrm{min}$ ) under a dynamic argon atmosphere on approximately 25-mg samples.

Application of Equations. (1) and (2) below enable the calculation of the amount of portlandite $(\mathrm{CH})$ and calcium carbonate from TG curves.

$$
\begin{aligned}
& \mathrm{CH}(\%)=W L_{\mathrm{CH}}(\%) \times \frac{M W_{C H}}{M W_{H}} \\
& \mathrm{CaCO}_{3}(\%)=W L_{\mathrm{CaCO}_{3}}(\%) \times \frac{M W_{\mathrm{CaCO}_{3}}}{M W_{\mathrm{CO}_{2}}}
\end{aligned}
$$

where $\mathrm{WL}_{\mathrm{CH}}(\%)$ and $\mathrm{WL}_{\mathrm{CaCO}_{3}}$ correspond to weight loss (\%) occurring during $\mathrm{CH}$ dehydration and $\mathrm{CaCO}_{3}$ decomposition, respectively. $\mathrm{MW}_{\mathrm{CH}}, \mathrm{MW}_{\mathrm{H}}, \mathrm{MW}_{\mathrm{CaCO}_{3}}$ and $M W_{\mathrm{CO}_{2}}$ are the molecular weights of portlandite, water, calcium carbonate and carbon dioxide, respectively. Infrared spectra were collected with a spectrometer (BioRad FTS 185 Digilab, USA) equipped with a Harrick scattering reflection device. Analysis was carried out on hydrated samples $(24 \mathrm{~h})$ diluted at $5 \%$ in $\mathrm{KBr}$. Spectra were converted by the Kubelka-Munk algorithm.

\section{Results and discussion}

\section{III.1. Calorimetric investigation}

The calorimetric curve of pure cement exhibits two distinct peaks (Figure 1). According to Sauvat et al. [17], they correspond to $\mathrm{C}_{3} \mathrm{~A}$ and $\mathrm{C}_{3} \mathrm{~S}$ hydration peaks respectively whereas Bensted et al. [18] suggested the reverse order in a very high $\mathrm{C}_{3} \mathrm{~A}$ containing cement. The shape of the curve, the time values and the thermogravimetric results suggest the first allocation. Three different times were defined as proposed by Sauvat et al., $t_{1}, t_{2}$ and $t_{3}$, which correspond to the minimal flux time, the first peak time and second peak time, respectively. The heat released in $48 \mathrm{~h}$ of hydration was determined by signal integration between $t_{1}$ and $t_{48} \mathrm{~h}$ (Table 2). The $t_{1}$ time, corresponding to the induction period increases from $0.4 \mathrm{~h}$ for pure cement to $1.2 \mathrm{~h}$ for natural Poplar-containing paste. Alberto et al. presented similar results with a tropical hardwood [19]. The heated Poplars slightly lengthen the induction period and the $t_{2}$ time compared to natural wood. The hydration of the silicate phase is significantly delayed and inhibited by wood. The natural Poplar increases the $t_{3}$ values and reduces the maximums of the corresponding heat flows. These phenomena are amplified by heated wood and are proportional to the treatment temperature. Consequently, the corresponding heat released values are much lower.

\section{III.2. Thermogravimetric and infrared spectroscopy investigations}

Several authors used differential thermal analysis (DTA) and thermogravimetric analysis (TGA) to investigate the effects of admixtures such as sugars or polysaccharides, on the hydration of the cement phases [12], [13], [14] and [20]. The thermogravimetric curve of the cement pastes exhibits five weight losses. The two first peaks, at 115 and $135{ }^{\circ} \mathrm{C}$ were assigned to ettringite and gypsum decomposition, respectively (Figure 2a). However, the decomposition peaks of ettringite and $\mathrm{C}-\mathrm{S}-\mathrm{H}$ overlap beyond $4 \mathrm{~h}$ of hydration. The gypsum consumption can be monitored until its complete disappearance since no other phase interferes with it. When the system becomes undersaturated with respect to sulfate, ettringite is converted into the monosulfoaluminate (MSA) by dissolution and reaction with the excess of $\mathrm{C}_{3} \mathrm{~A}$. This hydrate is detected beyond $16 \mathrm{~h}$ of hydration and its decomposition occurs at $185^{\circ} \mathrm{C}$ [13]. The thermal decomposition of $\mathrm{CH}$ and $\mathrm{CaCO}_{3}$ phases occurs between $420-480{ }^{\circ} \mathrm{C}$ and $600-750^{\circ} \mathrm{C}$, respectively.

The gypsum consumption is slower for $\mathrm{C}+20 \% \mathrm{P}$ formula than for pure cement (Figure $2 \mathrm{~b}$ ) since, the full consumption occurs beyond $8 \mathrm{~h}$ of hydration. However, the amount of ettringite is equal for $\mathrm{C}$ and $\mathrm{C}+20 \% \mathrm{P}$. This result seems paradoxical because ettringite results from 
consumption of gypsum. The presence of sulfate ions held in the wood was then investigated by ionic chromatography. The result showed that sulfate ions contained in wood are quickly solubilized in water. The same effect as the natural wood on ettringite and gypsum content is observed with heated Poplar at $260{ }^{\circ} \mathrm{C}$ (Figure 2c). However, during the first $8 \mathrm{~h}$ of hydration, the consumption of gypsum is slightly accelerated compared with $\mathrm{C}+20 \% \mathrm{P}$ formula. Therefore, the amount of ettringite formed during this time is enhanced. After treatment, the heated wood is less hygroscopic than natural wood [21]. Consequently, the amount of water available for the hydration of cement is higher for $\mathrm{C}+20 \% 260$ than for $\mathrm{C}+20 \% \mathrm{P}$. This result is consistent with Bensted observation [22] who showed that a high value of the W/C ratio accelerated the gypsum dissolution and promoted ettringite formation. In the first $8 \mathrm{~h}$ of hydration, the ability of wood to promote $\mathrm{C}_{3} \mathrm{~A}$. hydration is as follows: $\mathrm{C}+20 \%$ $260>\mathrm{C}+20 \% 240>\mathrm{C}+20 \% \mathrm{P}$ due to the modification of the hygroscopic behavior of the fiber by the heat treatment.

In pure cement, the decomposition peak corresponding to the monosulfoaluminate (MSA) appears between 16 and $24 \mathrm{~h}$ of hydration (Figure 2a). Its intensity still increases beyond $48 \mathrm{~h}$, which leads to a decrease in ettringite content. For the three composites, the MSA is not observable until $48 \mathrm{~h}$ of hydration on the thermogravimetric curves. Ettringite seems stabilized and its conversion into MSA is delayed. Seligmann and Greening observed the same phenomena by hydrating cement with a saccharose solution [23]. Collepardi et al. found that the addition of glucose, gluconate, or lignosulfonate stabilized ettringite in the $\mathrm{C}_{3} \mathrm{~A}$-gypsumlime system [13].

The decomposition peak of portlandite is less intense for the three composites than for C. Further information can be obtained by the calculation of portlandite content by Equation. (1). The formation of portlandite is stopped during the first $4 \mathrm{~h}$ and strongly inhibited beyond $48 \mathrm{~h}$ of hydration by natural Poplar (Figure 3). This inhibition could be linked to the partial absorption of water by wood particles, which leads to a decrease in the W/C ratio. Nevertheless, the Figure 3 shows that a W/C of 0.33 promoted the $\mathrm{CH}$ precipitation below $16 \mathrm{~h}$ of hydration. Consequently, the inhibition of $\mathrm{CH}$ formation is not due to the decrease in $\mathrm{W} / \mathrm{C}$ ratio. When cement is hydrated in presence of heat treated wood $\left(240\right.$ and $\left.260{ }^{\circ} \mathrm{C}\right)$, the induction period of $\mathrm{CH}$ is extended up to $8 \mathrm{~h}$ of hydration. Moreover, the amount of portlandite depends on the heat temperature of wood and is inversely proportional to the treatment strength. These results are consistent with the calorimetric investigation.

Silva et al. proposed that the smaller amount of portlandite observed for cement admixed with ethylene/vinyl acetate copolymer (EVA), could be associated with a greater carbonation of the cement pastes [24]. Figure 4 depicts the evolution of $\mathrm{CaCO}_{3}$ content in cement pastes during hydration. The amount of carbonate phases is strongly increased in the composites. This result is confirmed by infrared spectroscopy in the range $1420-1480 \mathrm{~cm}-1$ (Figure 5). It is possible to correlate the portlandite deficit, $\Delta \mathrm{CH}$ (mol/g of cement), and the carbonate excess, $\Delta \mathrm{CaCO}_{3}$ (mol/g of cement). These values are calculated by the Equations. (3) and (4), respectively. $\Delta C H(\mathrm{~mol} / \mathrm{g}$ of cement $)=\frac{C H_{\text {composite }}(\%)-\mathrm{CH}_{\text {cement }}(\%)}{100 \times M W_{C H}}$

$$
\Delta \mathrm{CaCO}_{3}(\mathrm{~mol} / \mathrm{g} \text { of cement })=\frac{\mathrm{CaCO}_{3 \text { composite }}(\%)-\mathrm{CaCO}_{3 \text { cement }}(\%)}{100 \times \mathrm{MW}_{\mathrm{CaCO}_{3}}}
$$

where $\mathrm{CH}_{\text {cement }}(\%), \mathrm{CaCO}_{3 \text { cement }}(\%), \mathrm{CH}_{\text {composite }}(\%)$ and $\mathrm{CaCO}_{3 \text { composite }}(\%)$ correspond to the amount of portlandite and calcium carbonate in cement and in wood cement composites, respectively. $\mathrm{MW}_{\mathrm{CH}}$ and $\mathrm{MW}_{\mathrm{CaCO}_{3}}$ are the molecular weights of portlandite and calcium carbonate, respectively (Figure 6).

For the three composites, the slope is equal to -0.3 . The correlation between $\mathrm{CH}$ deficit and $\mathrm{CaCOa}$ excess is about 30\%. This value is not high enough to explain completely the $\mathrm{CH}$ deficit. In a forthcoming study, it is shown that polysaccharides coming from wood fibers are hydrolyzed by cement media and converted into numerous carboxylic acids which are known 
to be powerful retarders [25]. Although the main retarding effect on cement hydration is attributed to alkaline degradation products, the inhibition of portlandite formation is extended by the carbonation of the pastes. Wood alkaline degradation could induce a carbon dioxide release. This $\mathrm{CO}_{2}$ leads to a carbonation of the portlandite. Consequently, the amount of $\mathrm{CaCO}_{3}$ in the paste increases. This hypothesis is consistent with the observation of the $\mathrm{NaOH}$ carbonation during a pulping process [26]. In this case, $\mathrm{NaOH}$ solution is used to hydrolyze the wood hemicelluloses.

Because it is not possible to monitor the $\mathrm{C}-\mathrm{S}-\mathrm{H}$ formation by thermal analysis at early age, it was monitored by infrared spectroscopy. The bands at 925 and $525 \mathrm{~cm}^{-1}$ in dry cement undergo changes during hydration. The shift of the $\mathrm{Si}-\mathrm{O}$ asymmetric stretching $\left(v_{3}\right)$ vibration to higher wave numbers $\left(970 \mathrm{~cm}^{-1}\right)$ and the change in the relative intensity of the Si-O out-ofplane bending vibration $\left(v_{4}\right)$ indicate the polymerization of the silicate units $\left(\mathrm{SiO}_{4}^{2-}\right)$ [27]. After $24 \mathrm{~h}$ of hydration, Figure 5 shows that $\mathrm{C}-\mathrm{S}-\mathrm{H}$ was formed for pure cement. The broad band centered on $930 \mathrm{~cm}^{-1}$ indicates that the $\mathrm{C}-\mathrm{S}-\mathrm{H}$ formation is delayed for the three composites. In $24 \mathrm{~h}$ old samples, the $\mathrm{Si}-\mathrm{O}$ stretching band was shifted by only $5 \mathrm{~cm}^{-1}$. This low shift suggests that there was very little polymerization of the silicates in the wood-cement composites, as proposed by Mollah et al. [28]. This result is confirmed by the slight change of the relative intensity of the $\mathrm{Si}-\mathrm{O}$ bending vibration at $525 \mathrm{~cm}^{-1}$.

\section{III.3. Influence of natural Poplar wood-to-cement ratio on hydration}

Table 3 shows the value of $t_{1}, t_{2}$ and $t_{3}$ obtained by calorimetry according to the increase in wood-powder content. The $t_{2}$ value is unchanged from $\mathrm{C}$ to $\mathrm{C}+7.5 \% \mathrm{P}$. It suggests that the kinetics of the $\mathrm{C}_{3} \mathrm{~A}$ hydration is similar even if for a low amount of wood it seems to be slightly accelerated. Wood particularly delays and inhibits the silicate phase and extends the length of induction period. The $t_{3}$ value increases from 8.8 to $12.2 \mathrm{~h}$ for wood content ranging from $2.5 \%$ to $7.5 \%$. This result confirms that the hydration of silicate phases is significantly delayed by natural wood.

The thermogravimetric curve of $\mathrm{C}+7.5 \% \mathrm{P}$ reveals an acceleration of the gypsum consumption compared with $\mathrm{C}+20 \% \mathrm{P}$. The corresponding amounts are close to those obtained for pure cement. The presence of sulfate ions in wood explains the higher amount of ettringite in $\mathrm{C}+7.5 \% \mathrm{P}$ formula than in pure cement. Moreover the gypsum being strongly consumed, the ettringite content increases compared with $\mathrm{C}+20 \% \mathrm{P}$.

The evolution of the portlandite content is shown in Figure 7. The induction period of $\mathrm{CH}$ in the $\mathrm{C}+7.5 \% \mathrm{P}$ formula is higher than in pure cement and lower than in cement admixed with $20 \%$ of natural fiber. The amount of calcium carbonate increases (Figure 8) whereas the amount of portlandite decreases with increasing natural Poplar content. The correlation between $\Delta \mathrm{CH}$ and $\Delta \mathrm{CaCO}_{3}$ for the two composites is reasonably similar (Figure 9). The slope of the curve is equal to -0.32 and -0.27 for $7.5 \%$ and $20 \%$ of wood, respectively. This result confirms that approximately $30 \%$ of the $\mathrm{CH}$ deficit is linked to its carbonation. This value is also slightly dependent of the wood content. The infrared spectroscopy reveals that $7.5 \%$ of natural Poplar inhibits the $\mathrm{C}-\mathrm{S}-\mathrm{H}$ formation.

\section{Conclusion}

The thermogravimetric investigation reveals a strong modification and delay of silicate phase hydration by wood particles. The corresponding induction periods are lengthened by the introduction of wood. The phenomenon is extended by heat treated Poplar. In composites, the amount of precipitated portlandite is lower than in pure cement. An increase in the amount of calcium carbonate phase explains partially (30\%) this inhibition. Infrared spectroscopy shows a strong delay in the precipitation of $\mathrm{C}-\mathrm{S}-\mathrm{H}$ when cement is hydrated with wood.

The hygroscopicity of natural wood particles tends to decrease the amount of free water. This phenomenon slows the dissolution and consumption of gypsum. The expected lack of sulfate ions is compensated by the dissolution of sulfate ions from Poplar fibers. Consequently, the amount of ettringite in wood-cement pastes is equal to or higher than in neat cement. 
Heat treatments improve dimensional stabilization and reduce the hygroscopicity of the wood fiber. Consequently, heated Poplar promotes gypsum dissolution or consumption and ettringite formation compared with natural Poplar. In the presence of natural and heat treated wood fibers, the ettringite is stabilized and its conversion into monosulfoaluminate is delayed.

\section{References}

[1] W. Sandermann, H.J. Preusser and W. Schwiens, The effect of wood extractives on the setting of cement-bonded wood materials, Holzforschung 14 (1960) (3), pp. 70-77.

[2] E.J. Biblis and C.F. Lo, Effect on the setting of southern pine-cement mixture, Forest Products J 18 (1968) (8), pp. 28-34.

[3] M.H. Simatupang, Abbaureaktionen von glucose, cellobiose und holz unter dem einfluss von portlandzementmörtel, Holzforschung 40 (1986), pp. 149-155.

[4] D.P. Miller and A.A. Moslemi, Wood-cement composites: species and heartwoodsapwood effects on hydration and tensile strength, Forest Products J 41 (1991) (3), pp. 9-14.

[5] D.P. Miller and A.A. Moslemi, Wood-cement composites: effect of model compounds on hydration characteristics and tensile strength, Wood Fiber Sci 23 (1991) (4), pp. 472482.

[6] Miller DP. Wood-cement composites: interactions of wood components with Portland cement. PhD thesis. Moscow, University of Idaho, 1988.

[7] V.F. Ficher, O. Wienhaus, M. Ryssel and J. Oldbrecht, The water-soluble carbohydrates of wood and their influence on the production of lightweight wood-wools boards, Holztechnologie 15 (1974) (1), pp. 12-19.

[8] R.L. Whistler and J.N. BeMiller, Alkaline degradation of polysaccharides, Adv Carbohydr Chem Biochem 13 (1958), pp. 289-329.

[9] Taplin JH. Discussion of paper by Vivian HE. Some chemical addition and admixtures in cement paste and concrete. In: Proceedings of 4 th international symposium on the chemistry of cement, vol. VII-1, Washington DC, 1960. p. 909-26.

[10] C.R. Wilding, A. Walter and D.D. Double, A classification of inorganic and organic admixtures by conduction calorimetry, Cem Concr Res 14 (1984), pp. 185-194.

[11] V.S. Ramachandran and M.S. Lowery, Conduction calorimetric investigation of the effects of retarders on the hydration of Portland cement, Thermochim Acta 195 (1992), pp. 373-387.

[12] J.F. Young, The influence of sugars on the hydration of tricalcium aluminate, Proceedings of the fifth international symposium on chemistry of cement vol. II-26, Cement Association of Japan, Tokyo (1968), pp. 256-267.

[13] M. Collepardi, S. Monosi, G. Moriconi and M. Pauri, Influence of gluconate, lignosulfonate or glucose on the $\mathrm{C}_{3} \mathrm{~A}$ hydration in the presence of gypsum with or without lime, Cem Concr Res 14 (1984), pp. 105-112.

[14] N.B. Milestone, Hydration of tricalcium silicate in the presence of lignosulfonates, glucose, and sodium gluconate, J Amer Ceram Soc 62 (1979) (7-8), pp. 321-324.

[15] H.F.W. Taylor, Cement chemistry, Academic Press, New York (1990).

[16] Guyonnet R., Bourgois J. Procédé de fabrication d'un matériau ligno-cellulosique par traitement thermique et matériau obtenu par ce procédé. FR Patent 2604 942, 10 October 1985 .

[17] N. Sauvat, R. Sell, E. Mougel and A. Zoulalian, A study of ordinary Portland cement hydration with wood by isothermal calorimetry, Holzforschung 53 (1999) (1), pp. 104108.

[18] J. Bensted, Some applications of conduction calorimetry to cement hydration, Adv Cem Res 1 (1987) (1), pp. 35-44.

[19] M.M. Alberto, E. Mougel and A. Zoulalian, Compatibility of some tropical hardwoods species with Portland cement using isothermal calorimetry, Forest Products J 50 (2000) (9), pp. 83-88. 
[20] A. Peschard, A. Govin, P. Grosseau, B. Guilhot and R. Guyonnet, Effect of polysaccharides on the hydration of cement paste at early ages, Cem Concr Res 34 (2004), pp. 2153-2158.

[21] A.J. Stamm, H.K. Burr and A.A. Kline, Staybwood, heat-stabilized wood, Ind Eng Chem 38 (1946) (6), pp. 630-634.

[22] J. Bensted, Early hydration of Portland cement-effects of water/cement ratio, Cem Concr Res 13 (1983), pp. 493-498.

[23] P. Seligmann and N.R. Greening, Studies of early hydration reactions of Portland cement by X-ray diffraction, Highway Res Record 62 (1964), pp. 80-105.

[24] D.A. Silva, H.R. Roman and P.J.P. Gleize, Evidences of chemical interaction between EVA and hydrating Portland cement, Cem Concr Res 32 (2002), pp. 1383-1390

[25] A. Govin, A. Peschard, E. Fredon and R. Guyonnet, New insights into wood-cement interaction, Holzforschung 59 (2005), pp. 330-335.

[26] E. Sjöström, Wood chemistry, fundamentals and applications (2nd ed.), Academic Press, New York (1993).

[27] J. Bensted, Some applications of infrared and Raman spectroscopy in cement chemistry: Part 3. Hydration of Portland cement and its constituent, Cem Technol (1974) (September/October), pp. 440-450.

[28] M.Y.A. Mollah, W. Yu, R. Schennach and D.L. Cocke, A Fourier transform infrared spectroscopic investigation of the early hydration of Portland cement and the influence of sodium lignosulfonate, Cem Concr Res 30 (2000), pp. 267-273. 


\section{Figures}

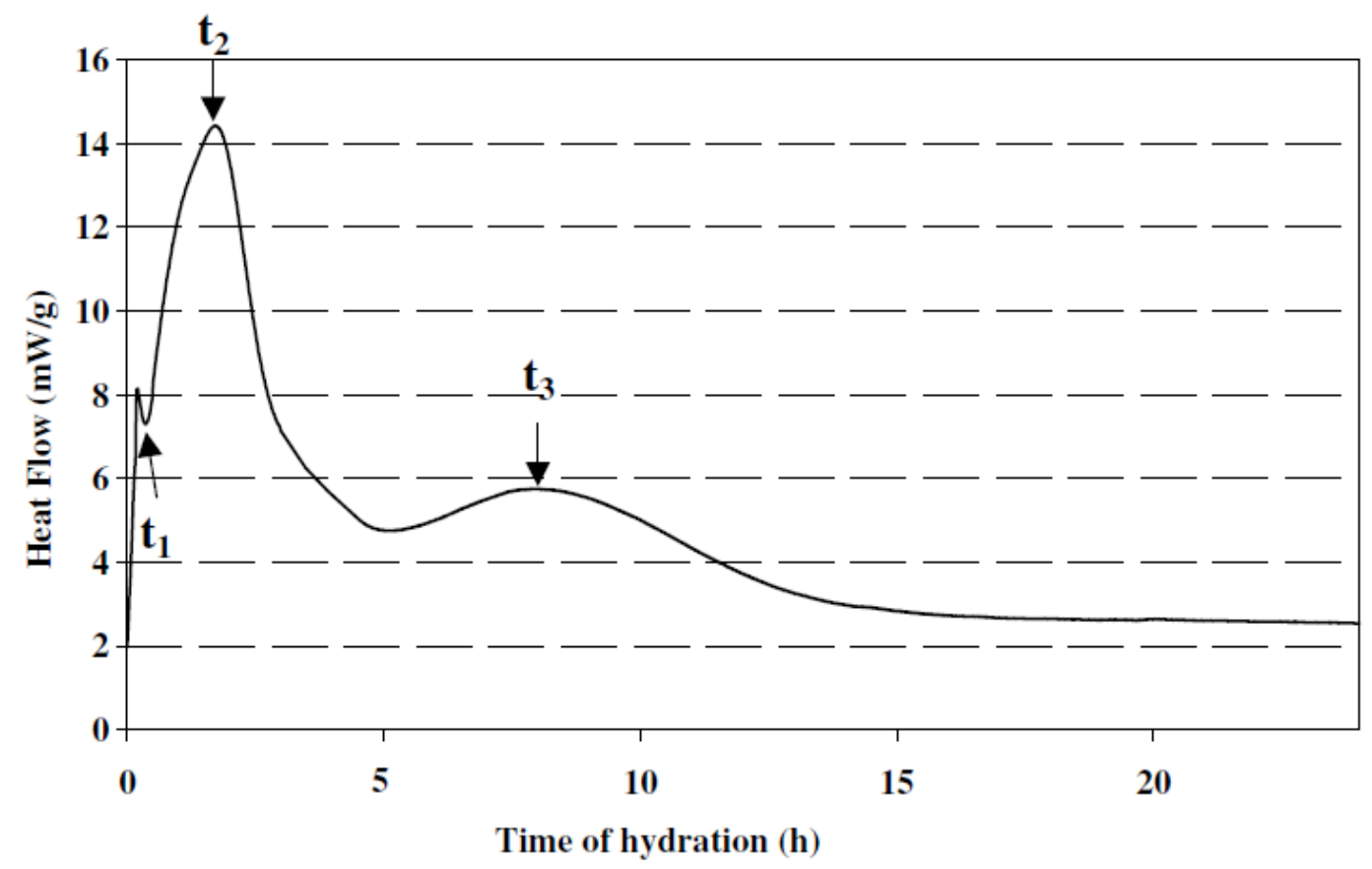

Figure 1: Three characteristic times of a calorimetric curve according to Sauvat et al. [17]. 

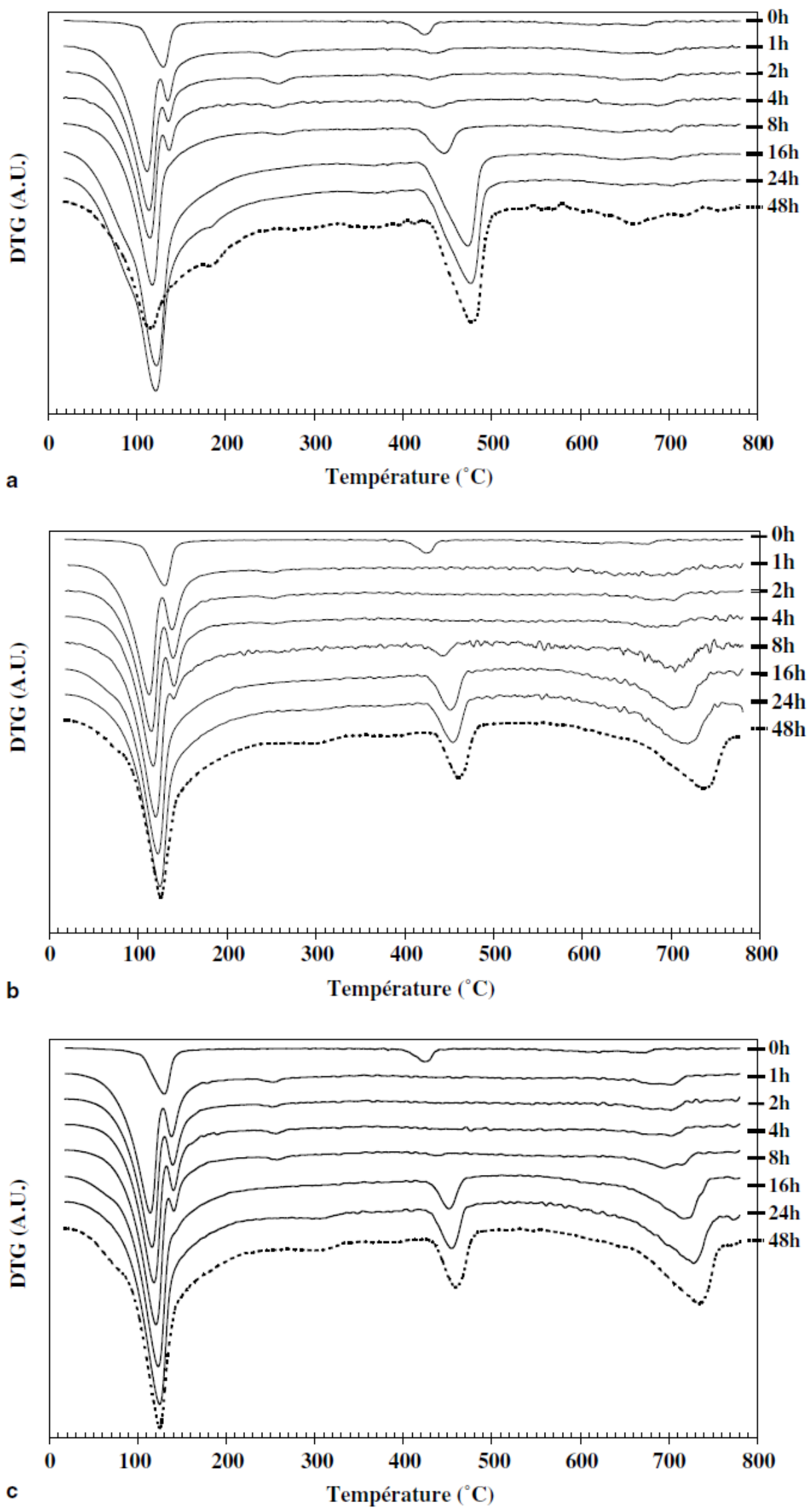

Figure 2: DTG curves of (a) pure cement, (b) C+20\% P and (c) C + 20\% 260 . 


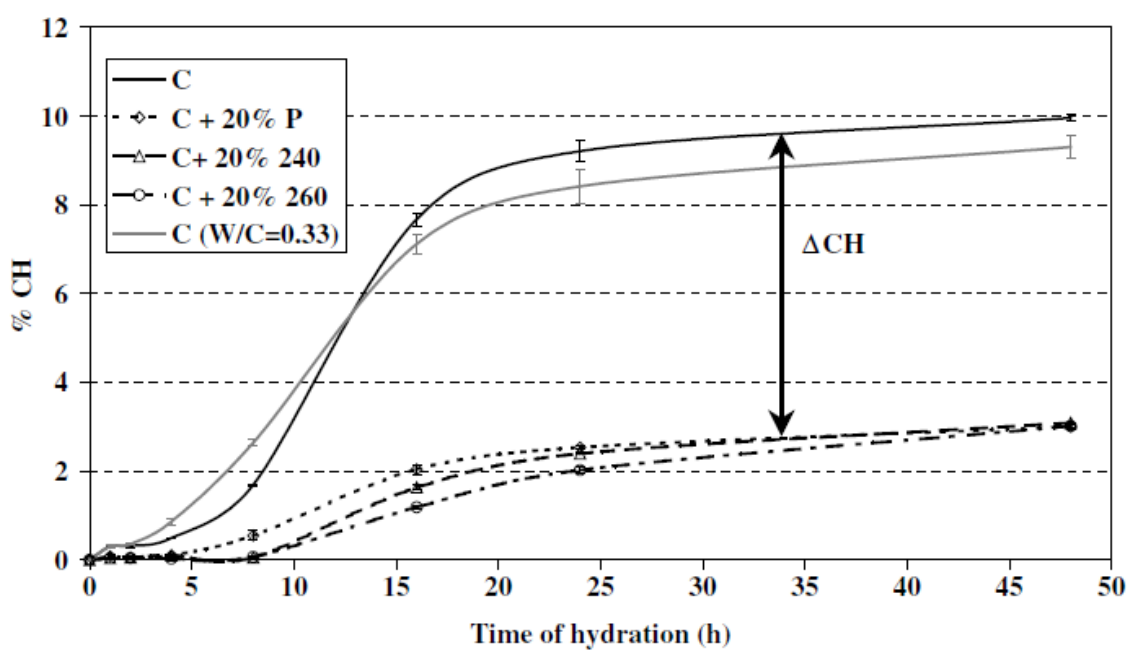

Figure 3: Influence of natural Poplar, heated Poplar and W/C ratio on the portlandite content in cement pastes.

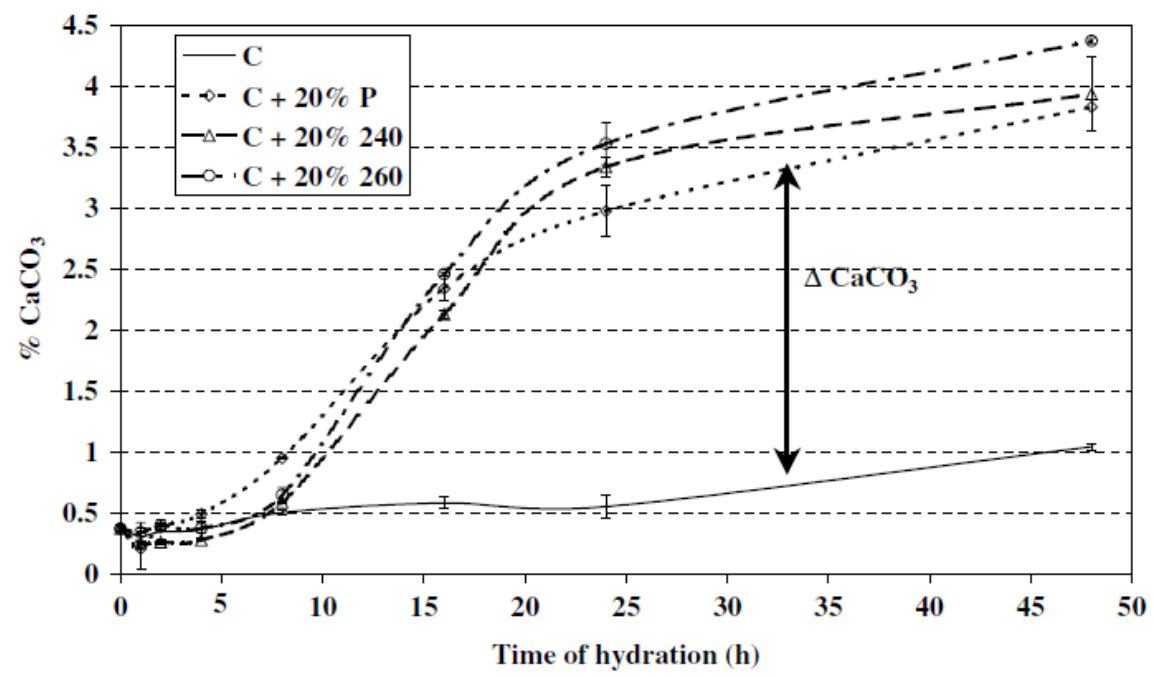

Figure 4: Influence of natural and heated Poplar on the calcium carbonate content in cement pastes.

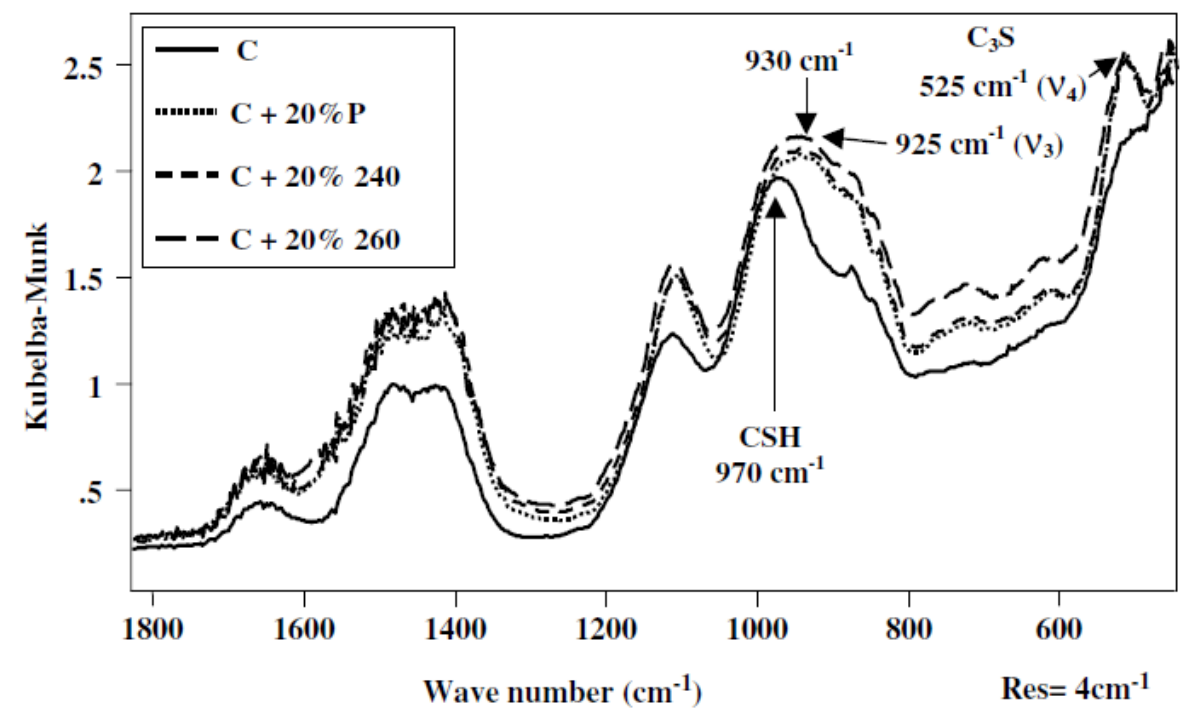

Figure 5: FTIR spectra of admixed cement pastes hydrated for $24 \mathrm{~h}$. 
Cement and Concrete Composites, 2006, 28(1), 12-20, doi:10.1016/j.cemconcomp.2005.09.002

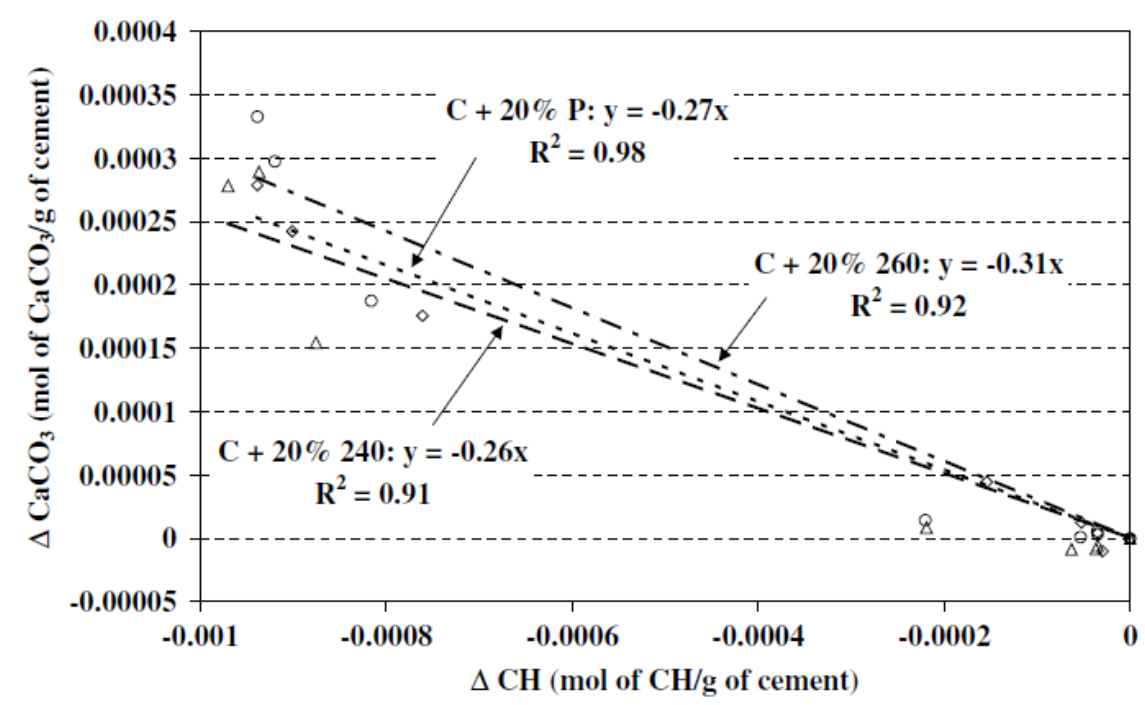

Figure 6: Correlation between the increase in $\mathrm{CaCO}_{3}$ content and the decrease in $\mathrm{CH}$ content in wood-containing pastes.

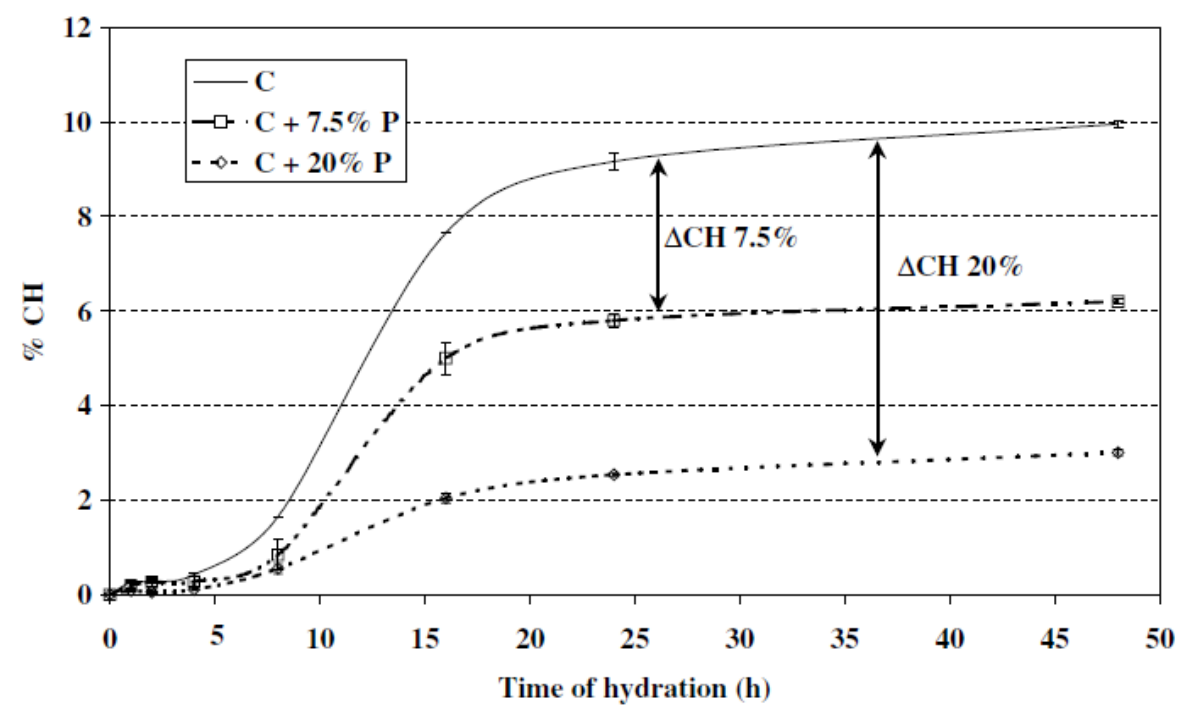

Figure 7: Influence of the natural wood-to-cement ratio on portlandite content in cement pastes. 
Cement and Concrete Composites, 2006, 28(1), 12-20, doi:10.1016/j.cemconcomp.2005.09.002

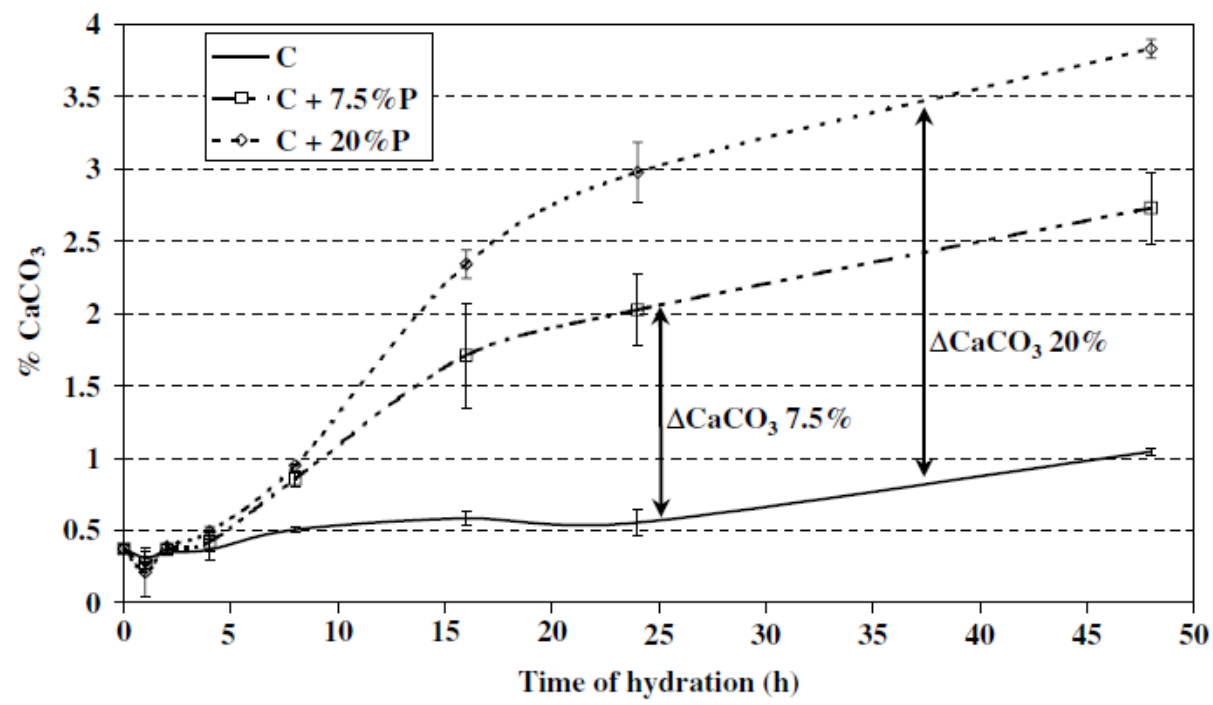

Figure 8: Influence of the natural wood-to-cement ratio on calcium carbonate content in cement pastes.

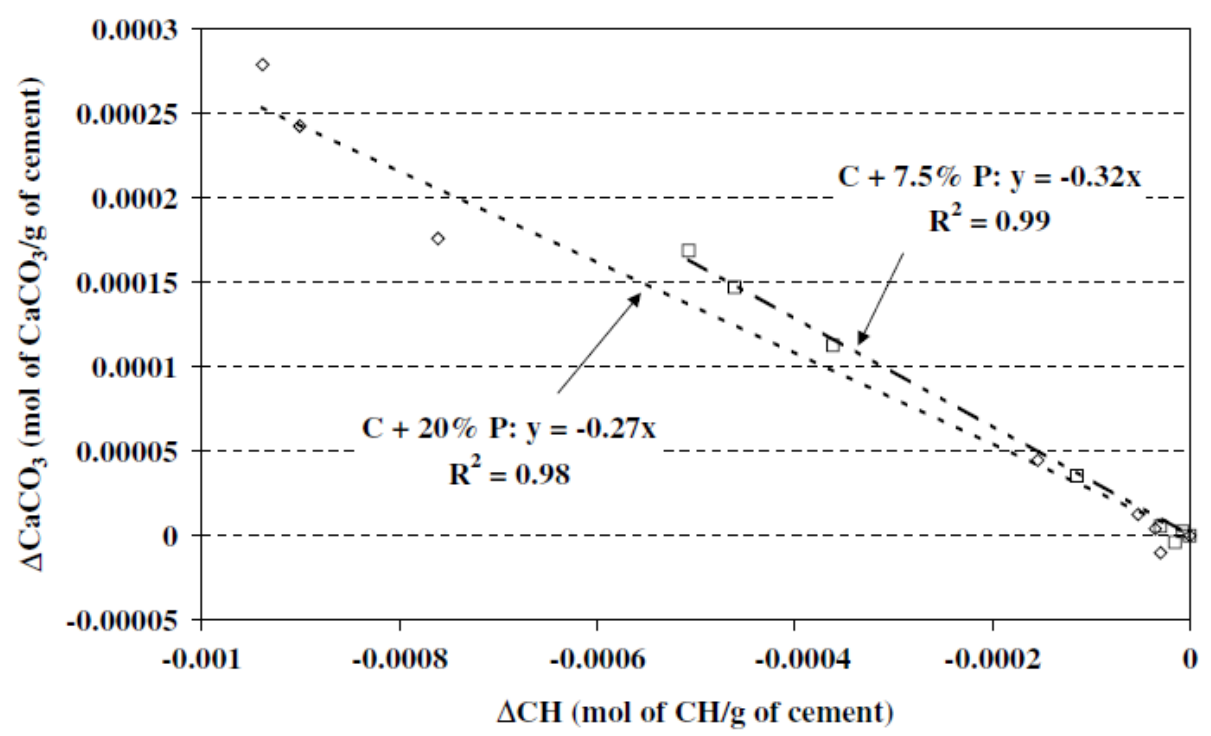

Figure 9: Influence of the natural wood-to-cement ratio on correlation between the increase in $\mathrm{CaCO}_{3}$ content and the decrease in $\mathrm{CH}$ content. 
Cement and Concrete Composites, 2006, 28(1), 12-20, doi:10.1016/j.cemconcomp.2005.09.002

\section{Tables}

Table 1: Chemical composition of cement and potential phases by Bogue approximation

\begin{tabular}{|l|l|}
\hline Chemical composition & Weight \% of components \\
\hline $\mathrm{SiO}_{2}$ & 19.98 \\
\hline $\mathrm{TiO}_{2}$ & 0.29 \\
\hline $\mathrm{Al}_{2} \mathrm{O}_{3}$ & 5.47 \\
\hline $\mathrm{F}_{2} \mathrm{O}_{3}$ & 2.72 \\
\hline $\mathrm{CaO}$ & 63.03 \\
\hline $\mathrm{MnO}$ & 0.03 \\
\hline $\mathrm{MgO}$ & 2.32 \\
\hline $\mathrm{Na}{ }_{2} \mathrm{O}$ & 0.46 \\
\hline $\mathrm{K}_{2} \mathrm{O}$ & 0.93 \\
\hline $\mathrm{P}_{2} \mathrm{O}_{5}$ & 0.26 \\
\hline $\mathrm{SO}_{3}$ & 5.14 \\
\hline $\mathrm{Bogue}_{2}$ Aproximation & \\
\hline $\mathrm{C}_{3} \mathrm{~S}$ & 64 \\
\hline $\mathrm{C}_{2} \mathrm{~S}$ & 9 \\
\hline $\mathrm{C}_{3} \mathrm{~A}$ & 10 \\
\hline $\mathrm{C}_{4} \mathrm{AF}$ & 8 \\
\hline
\end{tabular}

Table 2: Influence of natural and heated wood on characteristic times and heat released in $48 \mathrm{~h}$

\begin{tabular}{|l|l|l|l|l|}
\hline & $T_{1}(h)$ & $t_{2}(h)$ & $t_{3}(h)$ & $Q_{48 h}(J / g)$ \\
\hline$C$ & $0.4 \pm 0.1$ & $1.8 \pm 0.1$ & $8.1 \pm 0.2$ & $360 \pm 7$ \\
\hline$C+7.5 \% P$ & $1.2 \pm 0.2$ & $1.8 \pm 0.1$ & $12.2 \pm 0.3$ & $250 \pm 25$ \\
\hline$C+7.5 \% 240$ & $1.3 \pm 0.1$ & $1.9 \pm 0.2$ & $13.9 \pm 0.2$ & $190 \pm 12$ \\
\hline$C+7.5 \% 260$ & $1.6 \pm 0.1$ & $2.2 \pm 0.2$ & Undetermined & $140 \pm 9$ \\
\hline
\end{tabular}

Table 3: Influence of the natural wood-to-cement ratio on hydration times and enthalpy

\begin{tabular}{|l|l|l|l|l|}
\hline & $T_{1}(h)$ & $t_{2}(h)$ & $t_{3}(h)$ & $Q_{48 h}(J / g)$ \\
\hline$C$ & $0.4 \pm 0.1$ & $1.8 \pm 0.1$ & $8.1 \pm 0.2$ & $360 \pm 7$ \\
\hline$C+2.5 \% P$ & $0.8 \pm 0.1$ & $1.4 \pm 0.1$ & $8.8 \pm 0.2$ & $340 \pm 1 O$ \\
\hline$C+5 \% P$ & $0.9 \pm 0.1$ & $1.5 \pm 0.2$ & $9.5 \pm 0.3$ & $310 \pm 8$ \\
\hline$C+7.5 \% 26 O$ & $1.2 \pm 0.2$ & $1.8 \pm 0.1$ & $12.3 \pm 0.3$ & $25 O \pm 25$ \\
\hline
\end{tabular}

